\title{
Critical Analysis of Rabbit (Oryctolagus cuniculus) Meat Consumption in Abidjan, Cote D'ivoire
}

\author{
Djama Abo Nina1, Akoa Essoma Edwige Flore ${ }^{1^{*}}$, \\ Kra Kouassi Aboutou Séverin ${ }^{1}$, Mégnanou Rose-Monde ${ }^{1}$, \\ Otchoumou Kraidy Athanase ${ }^{1}$, Kouadio Natia Joseph ${ }^{1}$ \\ and Niamke Lamine Sébastien ${ }^{1}$ \\ ${ }^{1}$ Laboratory of Biotechnologies, Department of Biochemistry, UFR Biosciences, \\ Félix Houphouët-Boigny University, 22 BP 582 Abidjan 22, Côte d'Ivoire.
}

\begin{abstract}
Authors' contributions
This work was carried out in collaboration among all authors Author DAN took care of collecting the information from the field investigation. Author in AEEF was responsible for data processing and writing the article. Author KKAS was responsible for developing the survey sheets, validating the results and correcting the article. The other authors helped to prepare the survey sheets and to correct the article before submission. All authors read and approved the final manuscript.
\end{abstract}

Article Information

DOI: 10.9734/ARRB/2019/v34i530162 Editor(s):

(1) Prof. Jean-Marie Exbrayat, Université Catholique de Lyon, France. Reviewers:

(1) Sani Usman Bah, Yobe State University, Nigeria. (2) Cristina Hegedüs, University of Agricultural Sciences and Veterinary Medicine Cluj-Napoca, România. (3) Kamran Baseer Achakzai, Pakistan. Complete Peer review History: http://www.sdiarticle4.com/review-history/54349

Original Research Article

Received 10 December 2019

Accepted 14 February 2020

Published 24 February 2020

\section{ABSTRACT}

The aim of this paper was to study rabbit (Oryctolagus cuniculus) meat consumption in Côte d'Ivoire. To achieve this goal, a survey is conducted among consumers through a survey-valuation approach. Survey was carried out in 13 municipalities of Abidjan's district between September 2017 and May 2018. The survey collected data from 1950 respondents targeted in the Abidjan's district. In each municipality, 150 persons were interviewed, mainly in areas of great meeting such as car and bus stations, markets, restaurants and around schools. The method adopted in this work was random sampling. The data collection was done by self-counting (respondents completed the questionnaire themselves) and interview-assisted methods for each respondent. Results showed that rabbit meat is much appreciated by a large part of population $(74.36 \%)$. The main buyers of 
rabbit meat are restaurant managers (35\%) and households (35\%). Reasons of non-consumption of rabbit meat are unavailability $(49 \%)$, absence in eating habits $(22 \%)$ and high cost $(20 \%)$. Consumers ranked rabbit meat in third place compared to other meats (chicken, and sheep) consumed in Abidjan. 49.12\% found rabbit meat more expensive than other meats. Therefore, the adoption of effective trade strategies such as entrepreneurial, training, promotion in mass media, competitive pricing and market diversification, could make rabbit meat available and reduce the cost of sale. This could encourage the population to include rabbit meat more in their menus.

Keywords: Rabbit meat; level of consumption; consumers'opinion; preference; availability; feed cost.

\section{INTRODUCTION}

The global food market is undergoing many transformations, particularly in developing countries. These transformations are visible in the consumption habits of animal feed products. The change in consumption patterns is influenced by increased nutritional awareness. It also the standard living of a large number of citizens [1,2]. Breeding small animal species can be a good alternative. Indeed, this can bring significant benefits for households, both for shortand medium-term needs and in the long-term for savings [3]. Rabbit (Oryctolagus cuniculus) production has been identified as a major source of meat that can contribute to this objective. Rabbit meat is one of the most nutritious white meats available for human consumption. It is lower in fat, cholesterol, and calories, and higher in protein than beef, chicken, turkey, or pork [4]. Nutritionally, rabbit meat has a higher protein $(20-21 \%)$, lower calories (1749 $\mathrm{kcal} / \mathrm{kg})$ and lower fat content $(10-11 \%)$ compared to meat from most livestock species [5]. Furthermore, rabbit meat has the lowest cholesterol value of $169 \mathrm{mg} / 100 \mathrm{~g}$ (dry matter basis) when compared with beef $(200 \mathrm{mg})$, chicken $(220 \mathrm{mg})$ and pork (223 mg) and a low sodium content [6]. Consequently, rabbit meat has been listed in the USDA as an approved meat source for hypertensive patients [5]. Due to its nutritional attributes and easy digestion, rabbit meat is often recommended for people who need special diets, for example, patients with heart disease, diets for the elderly, low sodium diets, diets for weight loss [7]. In many developing countries, the rabbit is purposely bred to achieve self-sufficiency in home protein. Unfortunately, the production of rabbits, introduced as an alternative to remedy the shortage of protein, has not received sufficient attention. Despite of numerous economic and feeding potential of rabbit, apparently, Ivorian don't more consume rabbit meat and most of them considered rabbit meat as food of rich persons. These considerations have negative impact on the rabbit meat production. Faced with these difficulties, we believe that an understanding of attitudes in respect of rabbit meat will help its consumption and change consumer attitude towards rabbit meat products. An evaluation of rabbit consumption needs to be conducted for a comprehension of consumer comportment in order to outline possible strategies to ensure a sustainable future for the production of rabbits, for commercial meat purposes. Main objective is to reveal the opinion of the consumers of rabbit meat in order to be taken into account in the production systems.

\section{METHODOLOGY}

\subsection{Study Area}

The survey was carried out in Abidjan municipalities: Cocody, Koumassi, Treichville, Marcory, Abobo, Yopougon, Attécoubé, Adjamé, Port-Bouet, Plateau, Songon, Anyama and Bingerville, in Côte d'Ivoire, located between Latitude $5^{\circ} 00$ and $5^{\circ} 30$ North and Longitude $3^{\circ} 50$ and $4^{\circ} 10$ West. They cover $2120 \mathrm{~km}^{2}$, with 5.9 million in habitants.

\subsection{Consumer Survey}

The purpose of the survey was to assess the level of consumption of rabbit meat in Abidjan district. To achieve this goal, a survey is conducted among consumers. The survey collected data from 1950 respondents targeted from Abidjan's district between September 2017 and May 2018. In each municipality, 150 persons were interviewed, mainly in areas of great meeting such as car and bus stations, markets, restaurants and around schools. The method adopted in this work was random sampling. The data collection was done by self-counting (respondents completed the questionnaire themselves) and interview-assisted methods for each respondent. The consumption questions were divided into four (4) sections: the first for the profile of the respondent, the second for the 
rabbit knowledge, the third for the appreciation and the brakes on rabbit consumption and the last section for the population interest in rabbit production.

The responses were converted into quantitative data, on which statistical analyses were performed through on SPSS Software Version 17.0. These quantitative data consisted in the number or/and the percentages of respondent. Then, the chi-square test determined the influence of the socio-demographic characteristics of the respondents on their choices.

\section{RESULTS AND DISCUSSION}

\subsection{Customer Base of the Rabbit Meat}

The main buyers of rabbit meat are restaurant managers (35\%) and households (35\%) (Fig. 1). Next, supermarkets and ranchers are the other customers for $15 \%$ each. These results show that the rabbit meat customers are relatively varied. But that efforts should be made to improve its availability in supermarkets. In Kenya, the main consumers of the rabbit products are majorly local households, local hotels and restaurants, and about 5 per cent are exported [8]. He also further reported that market availability remained the major challenge. Commercial rabbit operations may be encouraged. Indeed, more sophisticated market infrastructure may involve product diversification such as tanned skins and processed meat forms, as well as entrepreneurial training, promotion in mass media, competitive pricing and market diversification. By adopting such a logistical development approach, a greater assurance of the sustainable increase of rabbit meat can be achieved.

\subsection{Socio-demographic Parameters of the Consumers}

Table 1 presents socio-demographic parameters of consumers. The survey revealed that among the 1,950 people interviewed in the district of Abidjan, $74.36 \%$ of persons are rabbit meat consumers and $25.64 \%$ of persons are no rabbit'consumers. This population is composed of $32.87 \%$ of female and $67.13 \%$ of male including, $20.97 \%$ of female and $53.39 \%$ of male are rabbit' consumers. Regarding the age, majors (20 to 49 years old) $(33.28 \%$ ) consume more rabbit meat than juniors (less than 20 years old) $(26.05 \%)$ and seniors (50 and over) $(5.03 \%)$. In France, 8 out of 10 peoples say they eat rabbit especially people aged 50 and over at $89 \%-91 \%$, the men at $87 \%$ [9]. All ethnic groups encountered in the district of Abidjan are rabbit consumers. The Akan group are the most consumers of rabbit $(33.64 \%)$ followed by the Northern Mande (15.54\%), Krou (7.38\%), Gur $(6.16 \%)$, foreigners $(6.00 \%)$ and finally Southern Mande $(5.64 \%)$. The mean reason is first able that Akan group are more Christian and secondary they don't keep socio-cultural taboo. The others reason is that Akan group disposed to a varied process of cooking animals' meat.

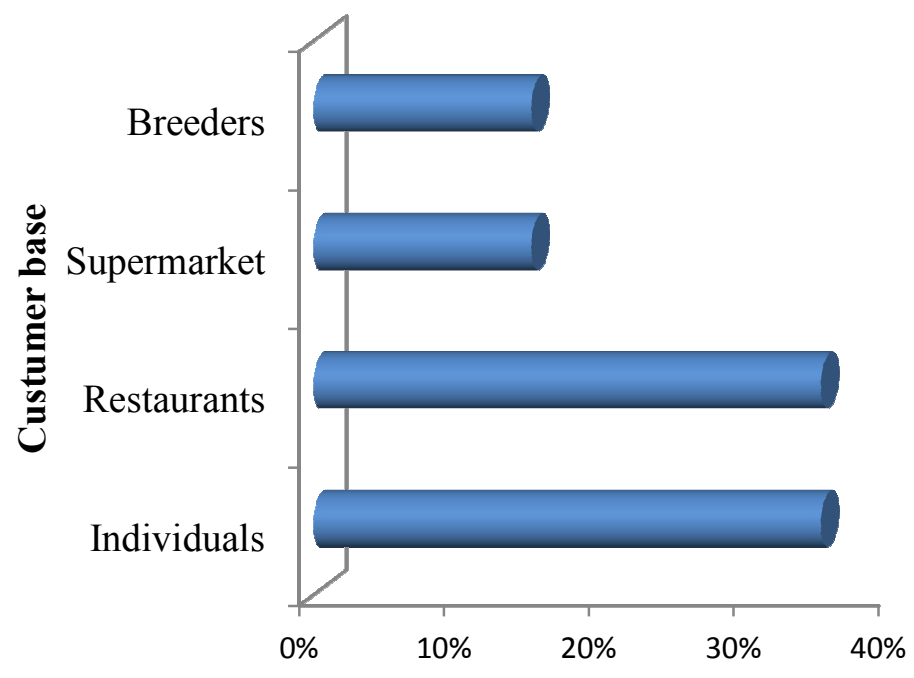

Fig. 1. Customer base of rabbit meat by producers 
As far as concern the level of education, $64.52 \%$ of literates are rabbit meat consumers. Customers are usually individuals and restorers. This work shows that more than half of the urban populations are consumers of rabbit meat. Akan and Northern Mande are the biggest consumers as well as the literate. Statistical analysis shows that the socio-demographic parameters of the respondents have an influence on rabbit consumption. Indeed, the level of consumption of the rabbit meat is strongly linked to sex, age, scholar level and ethnic group at $p(.00)<.05$. Results from a random sample of 1421 households in the southern United States suggest that the most likely consumers of rabbit meat are men, non-college graduates, those with household incomes at or below $\$ 50,000$, households with children, and Louisiana residents [10]. Socio cultural factors are the larger scale forces within societies and cultures that affect the thoughts behaviors and feelings of individual members of those societies and cultures [11]. It means that the socio cultural factors can affect deeply the choice of an individual. These issues can become very important for producers, because they need to target their promotions based on the socio cultural factors that are at play. Serving rabbit meat on festive community occasions, perhaps even disguising the meat for other more popular meats, is another proven means of gaining local acceptance. Besides such short-term approaches, providing rabbit meat in the school cafeterias and breeding stock for youth club rabbit projects are long term measures which can been successfully implemented for increasing rabbit meat production.

\subsection{Factors that Do Not Promote Rabbit Meat Consumption}

Prohibited and taboos (9\%) are major reasons hindering consumption of rabbit meat (Fig. 2). The survey showed that the consumption of rabbit meat was considered a taboo by a part of the population. Indeed, other studies have also shown that the rabbit is a taboo animal in some communities [12,13]. Rabbit raising in Ghana has been socially accepted; there are no social taboos regarding the consumption of rabbit meat [14]. Others reasons of non-consumption are absence in eating habits $(22 \%)$ and high cost of rabbit meat $(20 \%)$; the price of a $\mathrm{Kg}$ of rabbit is 3000 to 5000 CFA franc (US\$ 5.05 to 8.42) for Ivorian producers. However, the price of rabbit $\mathrm{Kg}$ is more expensive in Côte d'Ivoire than in Senegal (2500 to 3000 CFA franc/ Kg or US\$
4.21 to 5.05) [13]. But the majority of respondents $(49 \%)$ said the rabbit meat is not available. Several reasons make the rabbit an inaccessible meat. According to consumers, the availability and absence of eating habits is a brake on rabbit consumption. That is in accordance to the study of Bodnar et Howarth who had showed that the most frequent problem of Hungary consumer's is the lack of rabbit meat and rabbit products in the supermarkets in the country, so the urban citizens who like rabbit meat cannot buy it in their preferred shops [15]. The rabbit meat sold only in few supermarkets and the price is two or three times higher than the poultry meat [16]. In France, $20 \%$ of nonconsumers clearly identify the reasons for their choice: the fact that they consider the rabbit as a pet $(30 \%)$ or simply that they do not like the taste of the rabbit $(17 \%)$ and prefer other meats $(18 \%)$ [9]. In the Hungary, a great reason is that the culture of processing and cooking domestic rabbit meat is very poor; only $7 \%$ of the people could list more than 2 rabbit recipes. That is why people don't purchase rabbit meat [15]. In Nigeria, unavailability was cited as the most important factor hindering rabbit meat consumption [17]. In USA, respondents were more receptive to purchasing rabbit meat if it were packaged with recipes and cooking instructions (29 per cent) than to buying processed forms of the meat (23 per cent) or the meat if it were marinated (27 per cent) [10].

\subsection{Preference of Meat Sold by Consumers and Dearness of Rabbit Meat}

The survey revealed that chicken is the most popular meat followed by sheep (Fig. 3). Consumers ranked rabbit and beef meats in third place compared to other meats consumed by population of Abidjan. The fourth place is attributed to chicken. Goat and pork meats were ranked fifth and sixth respectively by respondents. The survey shows that rabbit meat occupies a fairly good position within the others meats. In Nigeria, despite the advantages of rabbits, its production and consumption was rated sixth after beef, mutton, chevon, fish and game [18]. In Nigeria, respondents liked rabbit meat and declared it palatable, yet they don't prefer it to other meat types probably because of their familiarity with others meats types which are readily available in the market and stores than rabbit meat [17]. Faced with this situation, some should make efforts to ensure that the current supply, and that rabbit meat is sold at a 
competitive price compared to popular meats [19]. However, opportunities for expansion should carefully consider the rabbit meat market demand [20].

Table 2 presents the ranking of meat sold in the markets according to their price by consumers. The survey reveals that respondents found rabbit meat more expensive than other meats. The least expensive meat according to consumers is chicken. In Kenya, the cost of beef, mutton and poultry is high like in the other sub Saharan countries [21]. The average consumer price of whole rabbits in metropolitan France was $€ 9.95 / \mathrm{kg}$ (6520 CFA franc/kg) [9]. The rabbit is the 3th favorite meat after chicken and sheep. Rabbits are the most expensive meat among consumers compared to other meats sold on the market. Respondents liked rabbit meat and declared it palatable, yet they don't prefer it to other meat types probably because of their familiarity with other meat types which are readily available in the market and stores than rabbit meat.

Table 1. Cross tabulations of rabbit consumption for socio-demographic characteristics with statistically significant coefficients

\begin{tabular}{|c|c|c|c|c|c|}
\hline \multicolumn{2}{|c|}{ Characteristics } & \multirow{2}{*}{$\begin{array}{l}\begin{array}{l}\text { No rabbit' consumers } \\
\text { (\%) }\end{array} \\
11.90\end{array}$} & \multirow{2}{*}{$\begin{array}{l}\begin{array}{l}\text { Rabbit' consumers } \\
(\%)\end{array} \\
20.97\end{array}$} & \multirow{2}{*}{$\begin{array}{l}\begin{array}{l}\text { Total } \\
(\%)\end{array} \\
32.87\end{array}$} & \multirow{2}{*}{$\begin{array}{l}\begin{array}{l}\text { Chi } \\
\text { square }\end{array} \\
73.44^{\mathrm{a}}\end{array}$} \\
\hline Sex & Female & & & & \\
\hline & Male & 13.74 & 53.39 & 67.13 & \\
\hline \multirow[t]{3}{*}{ Age } & Less than 20 & 8.82 & 26.05 & 34.87 & \multirow[t]{3}{*}{$67.18^{a}$} \\
\hline & 20 to 49 & 13.69 & 33.28 & 46.97 & \\
\hline & 50 and over & 3.13 & 5.03 & 8.16 & \\
\hline Ethnic & Akan & 10.31 & 33.64 & 43.95 & \\
\hline \multirow[t]{5}{*}{ group } & Krou & 1.80 & 7.38 & 9.18 & \multirow{4}{*}{$81.89^{a}$} \\
\hline & Gur & 2.46 & 6.15 & 8.61 & \\
\hline & Northern mande & 3.85 & 15.54 & 19.39 & \\
\hline & Southern mande & 4.10 & 5.64 & 9.74 & \\
\hline & Foreigner & 3.13 & 6.00 & 9.13 & \\
\hline Scholar & Literate & 21.64 & 64.52 & 86.16 & $27.17^{\mathrm{a}}$ \\
\hline Level & Illiterate & 4.00 & 9.84 & 13.84 & \\
\hline
\end{tabular}

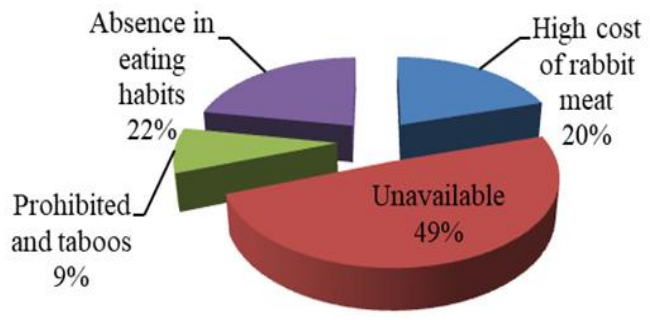

Fig. 2. Reasons for non-consumption of rabbit meat according to respondents

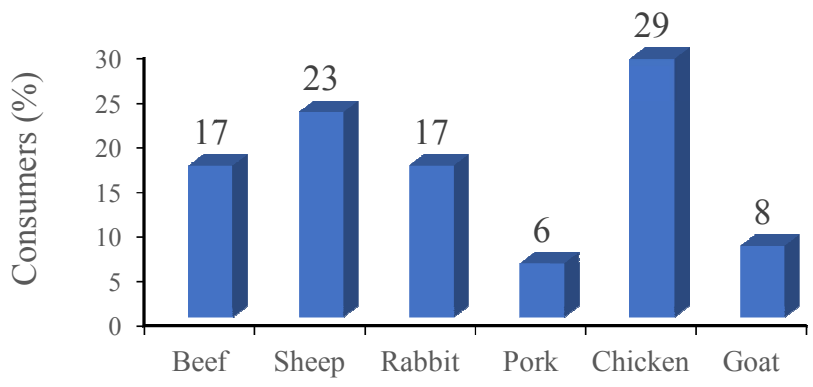

Fig. 3. Preference of the rabbit meat compared to other meats consumed in Abidjan 
Table 2. Order of expensive meat sold by consumers

\begin{tabular}{lllllll}
\hline Meats & Rabbit & Beef & Sheep & Pork & Goat & Chicken \\
\hline Dearness (\%) & 49.12 & 24.5 & 12.28 & 6.2 & 4.45 & 3.45 \\
Rank & First & Second & Third & Fourth & Fifth & Sixth \\
\hline
\end{tabular}

\section{CONCLUSION}

The present study has been started to identify population's opinion on consumption of rabbit meat. Results had showed that rabbit meat is much appreciated by a large part of population. The main buyers of rabbit meat are restaurant managers and households. But, the unavailability and high cost of rabbit meat are a brake on his massive consumption by population. However, the rabbit meat is the 3th favorite meat with beef after chicken and sheep. Therefore, the adoption of effective trade strategies such as entrepreneurial, training, promotion in mass media, competitive pricing and market diversification, could make rabbit meat available and reduce the cost of sale. This could encourage the population to include rabbit meat more in their menus.

\section{COMPETING INTERESTS}

Authors have declared that no competing interests exist.

\section{REFERENCES}

1. Variyam JN, Golan E. New health information is reshaping food choices. Food Review. 2002;25(1)(Spring):13-18.

2. Mensah JO, Aidoo R, Amponsah D, Buah AE, Aboagye G, Acquah-Harrison NS. Assessing the feasibility of commercial meat rabbit production in the Kumasi metropolis of Ghana. Am. J. Exp. Agr. 2014;4(2):183-192.

3. Kristensen E, Schou CK, Kyysgard CN, Madsen J, Henriksen J. Livestock production - The twenty first century's food revolution (Discussion paper on the donor community's role in securing a poverty oriented commercialization of livestock production in the developing world). Livestock Research for Rural Development. 2002;16(1).

[ISSN 0121-3784 (online edition)]

4. Eaudike Commercial Rabbits. Interesting Facts about Rabbits. Online under; 2003. Available:http://www.eaudikerabbits.co.uk/l inksandinfo.htm
5. USDA (United States Department of Agriculture). The ABCs of Domestic farm raised rabbit meat. Circular No. 549, Washington D.C. 1973;44-49.

6. Janieri A. Nutritional quality of rabbit meat. Italian R.V. Agriculture. 1987;24:275.

7. NARCI (North American Rabbit Cooperative, Inc.). Rabbit the Other White Meat; 2003.

Available:http://www.narci.info/food.htm

8. Karanja GN. Factors influencing the growth of agribusiness enterprises in kenya: $A$ case of rabbit farming in Kiambu county. International Journal of Economics and Finance. 2013;1(3):1-11.

9. Gomant F. Etude sur l'image de la viande de lapin et de la filière cunicole en 2018. IFOP - Département Opinion et Stratégies d'Entreprise - Paris, CUNICULTURE Magazine. French. 2018;45:27-30.

10. Meghan NB, McLean-Meyinsse EP, Cheryl A. An analysis of household consumption of rabbit meat in the Southern United States. J. Food Distrib. Res. 2004;35(1): 24-29.

11. Lukefahr SD, Cheeke PR. Rabbit project planning strategies for developing countries (2): Research applications. Livestock Research for Rural Development. 1990;2(3).

[Accessed:11 October 2018]

Available:http://www.cipav.org.co//rrd/Irrd2/ 3/cheeke2.htm

12. Lebas F. Le lapin, élevage et pathologie (nouvelle version révisée). Collection FAO : production et santé animales. Rome, Italie, $N^{\circ}$ 19. French. 1996;219.

13. Nteme EGS. Contribution à l'étude de la filière du lapin de chair (Oryctolagus cuniculus) au Sénégal. Thèse de Médecine et vétérinaire, $N^{\circ} 14$. 2000;132.

14. Mamattah N. Sociological aspects of introducing rabbits into farm practices. Workshop on Rabbit Husbandry in Africa, Morogoro, Tanzania. 1978;93-98.

15. Bodnar K, Horvath J. Consumers' opinion about rabbit meat consumption in Hungary. Management and Economy. $9^{\text {th }}$ World Rabbit Congress - June 10-13, 2008 Verona - Italy; 1919-1922. 
16. Colin M, Szórád I, Le Roux JF. Rabbit production in Hungary recent trends. In: Proc. $6^{\text {th }}$ World Rabbit Congress, July, Toulouse, France, CD-ROM. 1996;3.

17. Maigida R, Kabir MS, Jibir M. Attitudes to rabbit meat and problems associated with its consumption In Sokoto Metropolis. Int. J. Eng. Sci. 2018;7(9):08-12.

DOI: $10.9790 / 1813-0709010812$

18. Onifade AA, Obuvan AO, Fabanikanda OT. Rabbit Production in Nigeria: Some aspects of current status and promotional strategies. World Rabbit Sci. 1999;7(2): 51-58.

19. Hoffman LC, Nkhabutlane $P$, Schutte De W, Vosloo C. Factors affecting the purchasing of rabbit meat: A study of ethnic groups in the Western Cape. J. of
Family Ecology and Consumer Sciences. 2004;32:26-35.

20. Lukefahr SD. Strategies for the development of small and medium-scale rabbit farming in South-East Asia. Paper presented at the International Conference on Rabbit Production, Bogor, Indonesia, July 24-25, 2007, sponsored by the Indonesian Branch of the World Rabbit Science Association. Livestock Research for Rural Development. 2007; 19(9).

[ISSN 0121-3784]

21. Shadrack MK, Lawrence KK, Job KL, Walter K. Evaluation of technical efficiency of rabbit production in Buuri Sub-County, Meru County, Kenya. Adv. In Life Sci. Technol. 2016;49:1-13.

(c) 2019 Nina et al.; This is an Open Access article distributed under the terms of the Creative Commons Attribution License (http://creativecommons.org/licenses/by/4.0), which permits unrestricted use, distribution, and reproduction in any medium, provided the original work is properly cited.

Peer-review history:

The peer review history for this paper can be accessed here: http://www.sdiarticle4.com/review-history/54349 